\title{
Penetapan lebar jalur hijau mangrove berdasarkan aspek ekologi dan sosial ekonomi di Desa Sawah Luhur, Kota Serang, Banten
}

\author{
Determination of mangrove green belt width based on the ecological and socio-economic aspect \\ in Sawah Luhur Village, Serang City, Banten
}

\author{
LUTHFIA ZAHRA ZEN, SRI RAHAJU, YULIUS HERO \\ Departemen Manajemen Hutan, Fakultas Kehutanan, Institut Pertanian Bogor. Darmaga, Bogor 16680, Jawa Barat
}

Manuskrip diterima: 26 Desember 2011. Revisi disetujui: 19 April 2012.

\begin{abstract}
Zen LZ, Rahaju S, Hero Y. 2012. Determination of mangrove green belt width based on the ecological and socio-economic aspect in Sawah Luhur Village, Serang City, Banten. Bonorowo Wetlands 2: 52-65. The aims of this study was to examine the green belt policy and environmental condition in the coastal area of Sawah Luhur Village, Kasemen Sub-district, Serang City, Banten, and determine the decision-making solution of green belt policy in the village refers to ecological and socio-economic aspects. This study was based on primary and secondary data. Policy review was based on Presidential Decree (Keppres) no. 32 of 1990 on Protected Forest Area and Serang City Regulation (Perda) no. 6 of 2011 on Spatial Planning of the Region. Biophysical studies were conducted through ground checks and classified land into agricultural land, farms, settlements, forested areas, buffer zones, rivers, and roads. The socioeconomic study was conducted through interviews with 30 respondents, i.e., community, government officials in the villages, subdistricts, cities, and students. Based on the Presidential Decree, with the average difference of seawater tides being $0.7 \mathrm{~m}$, the width of the green belt in Sawah Luhur coastal area is $91 \mathrm{~m}$, and with the length of the coastline is $4.97 \mathrm{~km}$, then the green belt area is 45.18 ha. However, ground checks indicate that the mangrove green belt area only covers $50.19 \%$ or 22.68 ha, mainly consisting of Pulau Dua Nature Reserve. Therefore, the extent of the green belt is not implemented optimally in accordance with the Presidential Decree. In the Serang City Regulation, the determination of the green mangrove belt is not explained. Currently, the people of Sawah Luhur Village have difficulty meeting the needs of clean water due to the intrusion of seawater that reaches $4 \mathrm{~km}$ to the mainland, exacerbated by drought due to the long dry season. Besides, pollution and environmental degradation reduce pond productivity and agriculture, thus affecting the majority of people's income. To increase land productivity, one of them is by exploiting and planting coastal areas. According to respondents, coastal land is better utilized as a silvofishery (tambak tumpangsari) because it has ecologically, economically, and tourism advantages. If silvofishery can be realized and utilized properly, all parties will benefit in various aspects.
\end{abstract}

Keywords: Coastal area, green belt, mangrove, Sawah Luhur, pond

\section{INTRODUCTION}

Indonesia merupakan negara kepulauan yang terdiri atas lebih dari 17.508 buah pulau besar dan kecil dengan panjang garis pantai sekitar $81.000 \mathrm{~km}$ (Pusat Riset Teknologi Kelautan 2002). Tingginya potensi di wilayah pesisir menyebabkan laju pemanfaatan sumberdaya di kawasan mangrove semakin meningkat, yang berakibat pada kerusakan ekosistem mangrove yang tinggi (DKP 2007). Hal ini menimbulkan berbagai dampak yang besar bagi ekologi, ekonomi, serta sosial di wilayah pesisir. Dampak yang terjadi mengakibatkan kawasan ini menjadi isu penting dalam penentuan jalur hijau (green belt) kawasan mangrove.

Keppres No. 32 Tahun 1990 mengenai Pengelolaan Kawasan Lindung memberikan perlindungan yang lebih memadai terhadap zona jalur hijau. Menurut Keppres tersebut, jalur mangrove pantai minimal 130 kali rata-rata pasang yang diukur ke darat dari titik terendah pada saat surut. Konstanta 130 diperoleh dari hubungan antara produksi organik hutan mangrove dengan kehidupan biota perairan pantai dengan kisaran pasang surut, yaitu $400 \mathrm{~m}$ jalur hijau terhadap tinggi pasang surut $5 \mathrm{~m}$. Sesuai rumus maka batas lebar jalur hijau mangrove di Indonesia berkisar antara 52-702 m tegak lurus dari garis pantai atau tepi sungai.

Namun, kebijakan pemerintah tersebut hanya berdasarkan aspek ekologi, sehingga belum dapat menjawab permasalahan terhadap aspek sosial dan ekonomi. Perilaku masyarakat yang bersifat konvensional sesuai budaya setempat memandang ekosistem mangrove sebagai suatu karunia yang harus dimanfaatkan semaksimal mungkin, tanpa memandang tingkat kerusakan dan degradasi ekosistem tersebut. Kegiatan masyarakat dalam pemanfaatan ekosistem mangrove umumnya dilakukan berdasarkan kepentingan individu, cenderung mengeksploitasi dan merusak ekosistem mangrove untuk berbagai macam kepentingan pribadi dan kelompok, sehingga terjadi benturan kepentingan yang pada akhirnya bermuara pada keinginan untuk mendapatkan keuntungan secara ekonomi tanpa memperhatikan dampak secara ekologis.

Kebijakan yang relevan dalam penentuan lebar jalur hijau (green belt) mangrove dapat diperoleh dengan melakukan penetapan lebar jalur hijau mangrove berdasarkan aspek ekologi dan aspek sosial ekonomi, yang dapat dimanfaatkan untuk pengambilan keputusan yang 
lebih bijaksana dalam pengelolaan ekosistem mangrove secara berkelanjutan.

Penelitian ini dilakukan di Desa Sawah Luhur, Kecamatan Kasemen, Kota Serang, Banten, dengan tujuan (i) mengkaji kebijakan lebar jalur hijau (greenbelt) di wilayah pesisir desa tersebut, (ii) mengkaji keadaan lingkungan biofisik di wilayah pesisir desa tersebut, (iii) menentukan solusi pengambilan keputusan dalam kebijakan jalur hijau di desa tersebut sesuai dengan aspek ekologi dan sosial ekonomi.

\section{BAHAN DAN METODE}

\section{Tempat dan waktu penelitian}

Penelitian ini dilakukan di Desa Sawah Luhur, Kecamatan Kasemen, Kota Serang, Banten, pada bulan September sampai dengan Oktober 2011.

\section{Metode penelitian \\ Kajian biofisik}

Pengambilan data dilakukan dengan menggunakan data sekunder dan data primer. Parameter biofisik yang mempengaruhi keberadaan jalur hijau antara lain: penutupan lahan, vegetasi mangrove, substrat tanah/ lumpur, jangkauan pasang surut, tingkat abrasi, dan intrusi air laut (Hanson dan Koesoebiono 1977). Kerusakan sebagian atau seluruh vegetasi pantai tanpa kesadaran akan pentingnya jalur hijau akan menimbulkan bahaya intrusi air laut. Keberadaan jalur hijau didasarkan pada pemanfaatan wilayah hutan mangrove, tipe tanah, salinitas, lama penggenangan, dan kekuatan pasang surut (Koeswadji et al. 1986).

\section{Klasifikasi penutupan lahan}

Klasifikasi penutupan lahan ditentukan menggunakan citra satelit Quickbird tahun 2009. Citra satelit ini juga digunakan untuk pembuatan buffering lokasi pasang surut, intrusi air laut, vegetasi, dan salinitas air.

\section{Pengamatan lapangan}

Pengamatan lapangan berupa pengambilan titik pada obyek-obyek yang telah ditentukan pada identifikasi awal mengenai klasifikasi penutupan lahan (vegetasi, buffer zone, pemukiman, tambak silvofishery, tambak masyarakat, jalan raya, semak belukar, dan sawah); tujuannya untuk mengetahui kondisi aktual lokasi di Sawah Luhur.

Tanah, jangkauan pasang surut, tingkat abrasi, intrusi dan salinitas air laut

Pengambilan data tanah, jangkauan pasang surut, tingkat abrasi, intrusi dan salinitas air laut di lokasi penelitian berdasarkan penelitian Sualia (2010).

\section{Kajian kebijakan}

Kajian kebijakan mencakup Keppres No. 32 Tahun 1990 mengenai Pengelolaan Kawasan Lindung. Peraturan ini memberikan perlindungan yang lebih memadai terhadap zona jalur hijau. Selain itu juga mempertimbangkan kebijakan pemerintah daerah melalui penetapan RTRWP yang terdapat pada Perda Kota Serang No 6 Tahun 2011.

\section{Kajian sosial ekonomi masyarakat}

Data dan informasi sosial ekonomi masyarakat yang dikumpulkan bersifat deskriptif untuk menggambarkan atau mendeskripsikan seluruh fenomena dan fakta-fakta yang terkait dengan obyek kajian (Natzir 1999). Penentuan responden sebagai unit contoh dilakukan dengan metode purposive sampling, dimana penentuan contoh atas pertimbangan pribadi peneliti. Pertimbangan dalam penentuan responden yaitu responden berhubungan langsung dengan lingkungan penelitian, mencakup anggota masyarakat dan pelajar setempat serta aparat pemerintah (desa, kecamatan, kota). Jumlah responden secara keseluruhan adalah 30 orang. Metode ini bertujuan untuk mengetahui perilaku, interaksi dan tingkat kesejahteraan masyarakat di sekitar hutan mangrove. Parameter yang digunakan dalam kajian sosial ekonomi berkaitan dengan tata bangunan penduduk (rumah/bangunan), jalan atau jembatan, pemanfaatan lahan untuk tambak, pemanfaatan kayu oleh masyarakat, serta persepsi masyarakat terhadap lebar jalur hijau. Pengumpulan data sekunder diperoleh dari Badan Perecanaan Pembangunan Daerah Kota Serang, Banten (Bappeda 2008).

\section{HASIL DAN PEMBAHASAN}

\section{Kajian kebijakan pengelolaan kawasan pesisir pantai Serang}

Jalur hijau mangrove sangat penting bagi kelangsungan kehidupan terutama di wilayah pesisir pantai. Jalur hijau memiliki fungsi antara lain: (i) sumber produktivitas primer perairan, (ii) tempat berlindungnya organisme, (iii) stabilisator tempat pengendapan lumpur, dan (iv) penyangga terhadap angin, gelombang, arus, serta polutan yang berasal dari daratan, dan lautan. Dengan kata lain batasan jalur hijau pesisir adalah bagian hutan mangrove yang tetap dipertahankan yang berbatasan dengan pantai atau tepi sungai dengan sifat alaminya yang khas dapat mempunyai fungsi hayati, fisik, dan kimia perairan (Soemarno 1986).

Desa Sawah Luhur merupakan salah satu wilayah Kota Serang yang memiliki garis pantai dengan daratan relief yang rendah dan sempit (Gambar 1). Desa ini memiliki panjang garis pantai 4,97 km yang berbatasan langsung dengan Laut Jawa. Garis pantai yang rendah dan sempit berpotensi untuk terjadinya abrasi. Setelah dilakukan pengamatan di wilayah buffer zone, telah terjadi abrasi yang mengakibatkan rusaknya tanaman mangrove, sehingga menyebabkan wilayah garis pantai dan sekitarnya tidak dapat berfungsi sebagai jalur hijau.

Sawah Luhur memiliki daerah berhutan yang sekaligus berfungsi fungsi cagar alam, yaitu Cagar Alam Pulau Dua atau disebut pula Pulau Burung seluas 30 hektar. Cagar alam ini memiliki fungsi ganda yaitu pelindung habitat berbagai macam burung pantai dan berfungsi sebagai daerah penyangga. Hal ini tercantum dalam Perda Kota Serang No. 6 Tahun 2011. 


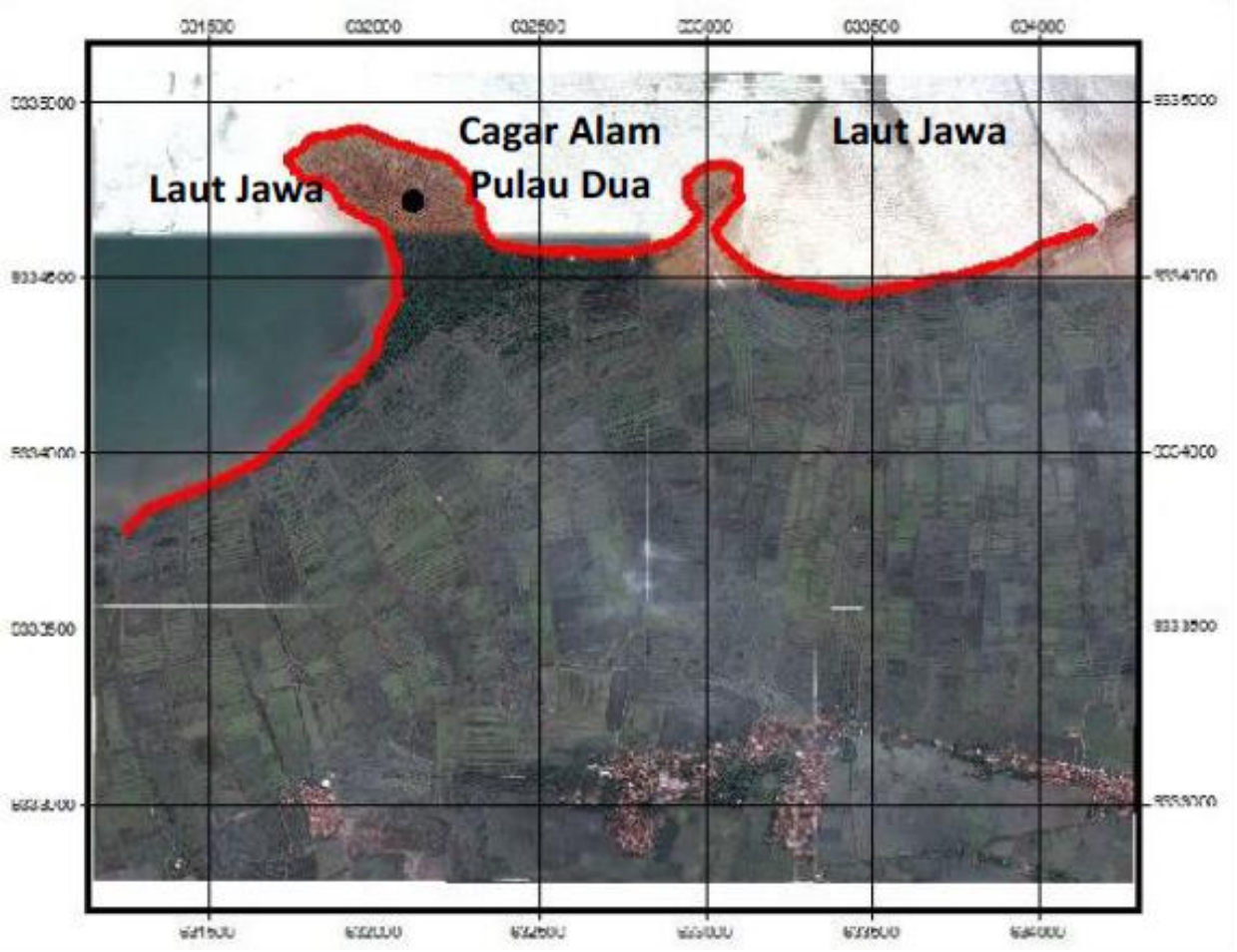

\section{Peta Garis Pantai Desa Sawah Luhur Kecarnatan Kasemer Kota Serang, Banten}
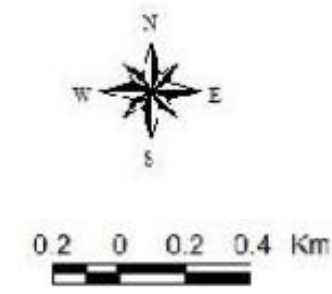

Keterangan:

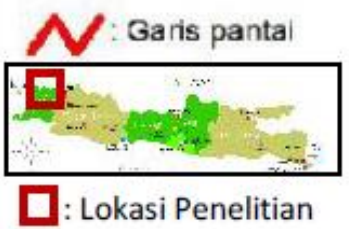

Gambar 1. Garis pantai Desa Sawah Luhur, Kota Serang, Banten

Daerah pesisir Sawah Luhur belum dapat dikatakan memenuhi standar jalur hijau. Berdasarkan Keppres No. 32 Tahun 1990, lebar jalur hijau di wilayah pesisir Sawah Luhur adalah $91 \mathrm{~m}$. Lebar ini diperoleh dari perhitungan konstanta 130 dikalikan dengan $0,7 \mathrm{~m}$ yang merupakan pasang surut rata-rata tahunan. Panjang garis pantai di Sawah Luhur adalah 4,97 km, sehingga dari lebar jalur hijau $91 \mathrm{~m}$, memiliki luasan jalur hijau adalah 45,18 ha. Tetapi di lapangan, dari luas jalur hijau 45,18 ha, wilayah yang ditumbuhi mangrove hanya $50,19 \%$ yakni seluas 22,68 ha yang sebagian besar berupa Cagar Alam Pulau Dua, dan sisanya berupa lahan kosong dan tambak. Wilayah jalur hijau berupa lahan kosong merupakan wilayah buffer zone yang terkena dampak dari abarasi air laut. Selain itu, wilayah ini juga banyak dimanfaatkan untuk kegiatan budidaya perairan air payau atau pertambakan.

Pada dasarnya kebijakan Keppres No. 32 Tahun 1990 memiliki kekurangan sehingga sulit untuk diterapkan di wilayah pesisir Sawah Luhur. Keppres tersebut memiliki beberapa kelemahan, sebagai berikut: (i) Keppres ini tidak dapat diterapkan pada areal yang saat ini tidak memiliki tumbuhan mangrove lagi karena adanya eksploitasi pada masa lalu atau konversi. Untuk itu, hendaknya diadakan penyesuaian yakni pada areal yang awalnya hanya memiliki vegetasi mangrove. (ii) Penentuan jalur hijau dengan menggunakan Keppres ini di pantai-pantai yang datar dan berlumpur yang luas tidak dapat digunakan secara efektif. Di beberapa daerah seperti di atas, lebar jalur hijau yang dihitung dari titik terendah saat air surut hanya berupa dataran lumpur saja dan tidak sampai ke hutan mangrovenya. Permasalahan ini dapat diatasi dengan mendefenisikan pengukuran dari hutan mangrove terluar dekat laut. (iii) Keppres ini tidak mengacu adanya perlindungan terhadap mangrove secara menyeluruh maupun fungsi ekologisnya. Keppres ini mengesampingkan adanya keterkaitan ekologis, misalnya dengan mangrove daratan, sumber air tawar atau dengan rawa air tawar. Tanpa adanya perlindungan terhadap ekosistem pendukung secara terpadu, kelangsungan hidup jalur hijau tersebut tidak akan terjamin sepenuhnya. (iv) Keppres ini hanya memberikan pilihan untuk konservasi. Pilihan tersebut umumnya tidak memadai pada daerah yang telah memiliki pemanfaatan tradisional yang intensif, sehingga akan menyulitkan tercapainya suatu konsesus pengelolaan mangrove di beberapa daerah. Misalnya di Jawa, hampir seluruh areal mangrove telah dimanfaatkan oleh penduduk, baik untuk tambak maupun berbagai bentuk pemanfaatan lainnya yang sebenarnya tidak mendukung konservasi mangrove.

Keppres ini juga hanya memandang jalur hijau dari aspek ekologi saja, sehingga akan berdampak terhadap kehidupan sosial ekonomi masyarakat. Kenyataanya wilayah Indonesia sebagian besar terletak di kepulauan dan masyarakat banyak yang tinggal di lingkungan pesisir. Untuk itu, pemerintah dapat mengambil solusi dalam penetapan jalur hijau yang lebih bijaksana dalam pengelolaan pesisir pantai secara terpadu.

Tujuan dari kebijakan pengelolaan kawasan pantai adalah untuk meningkatkan kesejahteraan masyarakat yang kehidupannya tergantung pada sumberdaya pesisir dan laut sekaligus melindungi keanekaragaman hayati, sehingga produktifitas sumberdaya tersebut dapat terjaga secara berkelanjutan. Pemerintah kota Serang telah membuat dan 
mengesahkan Perda No. 6 Tahun 2011 mengenai Rencana Tata Ruang Wilayah Kota Serang tahun 2010-2030. Peraturan pemerintah ini mencakup kebijakan-kebijakan yang berkaitan dengan tata ruang di wilayah pesisir Kota Serang.

Berdasarkan Perda No. 6 Tahun 2011 kawasan Sawah Luhur memiliki fungsi pemanfaatan lahan sebagai lahan pertanian, perikanan air payau, pemukiman sekunder, pariwisata dan perlindungan setempat. Untuk kawasan perlindungan disebutkan di wilayah sepadan sungai, pantai dan Cagar Alam Pulau Dua. Sawah Luhur juga merupakan bagian dari pengembangan ruang terbuka hijau di wilayah Kota Serang. Ruang terbuka hijau adalah area memanjang/ jalur dan/atau mengelompok, penggunaannya lebih bersifat terbuka, tempat tumbuh tanaman, baik yang tumbuh secara alamiah maupun yang sengaja ditanam. Pemanfaatan ruang terbuka hijau bertujuan untuk meningkatkan kegiatan pembangunan kesejahteraan masyarakat, investasi dan memelihara serta mencegah terjadinya kerusakan lingkungan hidup. RTRWP Kota Serang meliputi ruang terbuka hijau publik dan privat seluas paling sedikit $30 \%$ dari luas wilayah Kota Serang.

Berdasarkan Perda No. 6 Tahun 2011, ruang hijau di wilayah Sawah Luhur hanya mencakup Cagar Alam Pulau Dua, daerah sempadan sungai dan pantai. Dalam Perda ini tidak ada penunjukkan wilayah kawasan jalur hijau secara rinci. Hal ini bertentangan dengan Instruksi Menteri Dalam Negeri No. 26 Tahun 1997 yang mewajibkan setiap daerah menentukan lebar jalur hijau di wilayah mereka masingmasing. Apabila daerah pesisir pantai tidak memiliki kawasan penyangga (jalur hijau) akan berdampak pada ketidakseimbangan antara aspek lingkungan dan sosial ekonomi. Selain itu apabila pemerintah daerah menginginkan lingkungan pesisir yang terpadu dalam pengelolaannya, maka pemerintah daerah harus melibatkan stakeholders yang terkait kebijakan jalur hijau, terutama masyarakat setempat yang nantinya berperan langsung terhadap pengelolaan wilayah pesisir pantai.

\section{Kajian jalur hijau berdasarkan biofisik \\ Klasifikasi penutupan lahan}

Pengamatan lapangan dilakukan adalah dengan pengambilan 18 titik sampel yang telah ditentukan pada identifikasi awal pada klasifikasi penutupan lahan, yaitu: vegetasi, buffer zone, pemukiman, tambak tumpangsari (silvofishery), tambak masyarakat, jalan raya, dan sawah. Hal ini bertujuan untuk mengetahui kondisi aktual tutupan lahan di wilayah Sawah Luhur (Gambar 2).

\section{Pemukiman}

Pemukiman warga terpusat di antara lahan pertambakan yang tersebar di Dusun Manggarong, Padek Pancur, Kebasiran, sebagian Kebon Lama, Kebon Baru sedangkan untuk wilayah pertanian, terdapat Dusun Kacancang, Badamussalam, dan Cangkring.

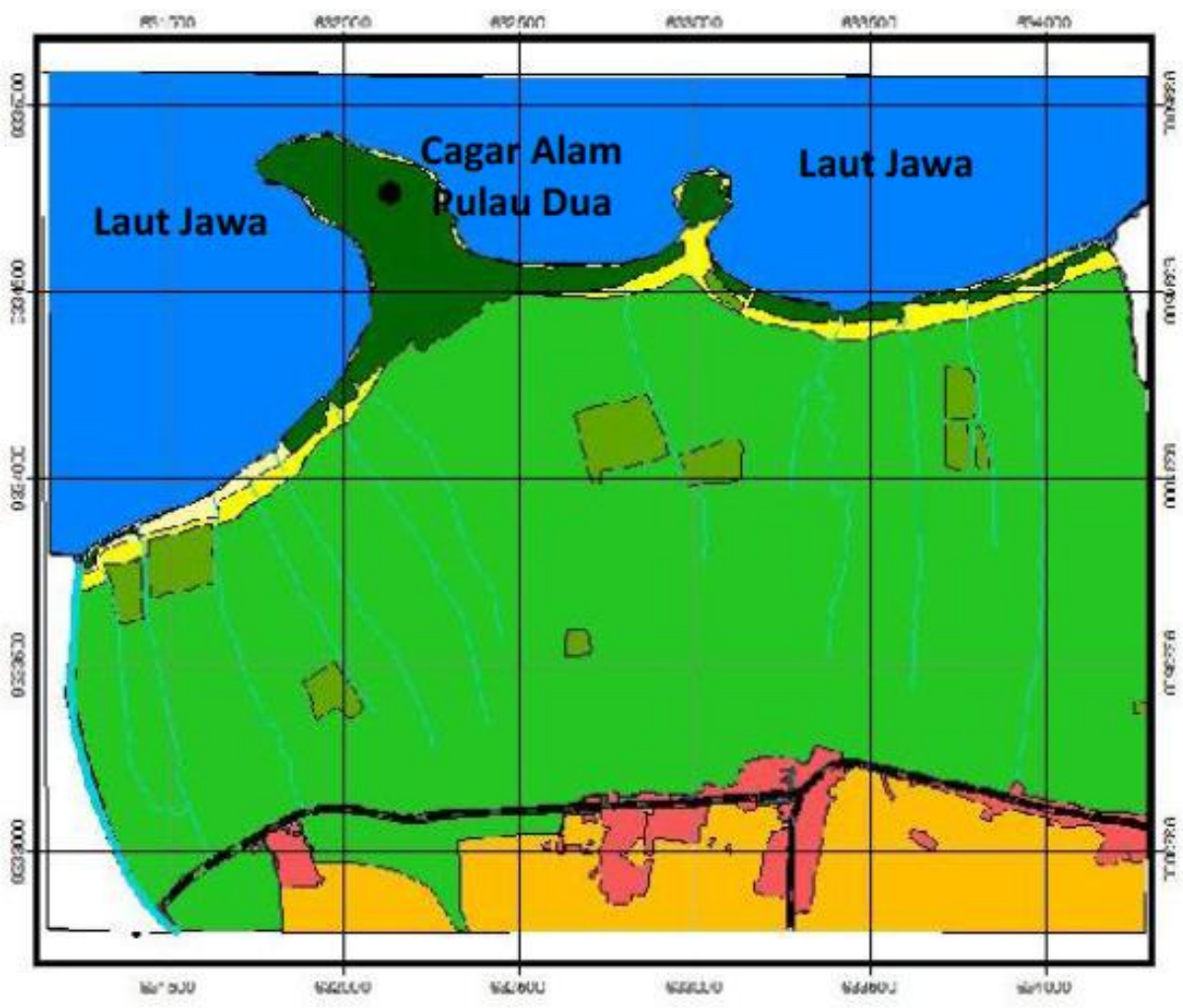

Gambar 2. Peta tutupan lahan Desa Sawah Luhur, Kota Serang, Banten

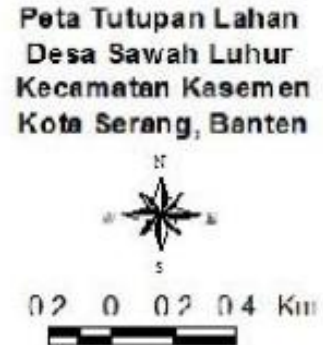

Keterançan:
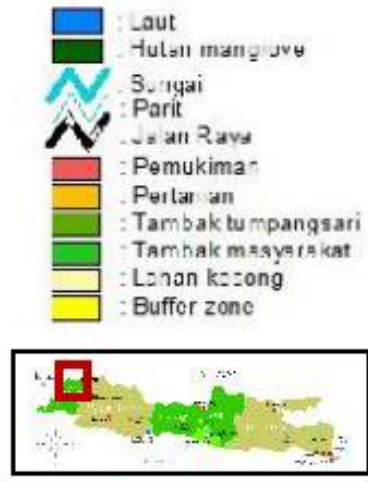

: Lokasi Penelitian 
Pada Gambar 3 terlihat kondisi salah satu sudut pemukiman di Sawah Luhur. Sebagian besar pemukiman dengan konstruksi semi permanen, dan infrastruktur yang kurang memadai; tanah sangat gersang dan berdebu. Menurut masyarakat, pemukiman yang ideal bagi mereka adalah memiliki fasilitas umum yang lengkap terutama ketersediaan air bersih. Terdapat satu dusun di Sawah Luhur yakni Dusun Kecancang yang letaknya jauh dari jalan raya. Untuk menuju ke lokasi dusun ini harus melewati jalan yang rusak dan pada musim penghujan sulit dilewati. Hal ini menyebabkan warga dusun tersebut sulit melakukan aktivitas. Selain itu fasilitas pengairan untuk lahan pertanian juga sangat sulit. Masyarakat harus membeli air dengan pendapatan pas-pasan dari penghasilan menjadi buruh tani.

\section{Pertanian}

Luas lahan untuk pertanian di Sawah Luhur adalah 900 ha atau mencapai $47,5 \%$ dari luas wilayah desa tersebut (Monografi Desa Sawah Luhur 2008). Hal ini menunjukkan mayoritas penduduk memiliki mata pencaharian di bidang pertanian, tetapi sebagian besar lahan pertanian tersebut bukan milik pribadi. Masyarakat hanya menjadi buruh tani atau menyewa lahan tersebut.

Pada saat penelitian dilakukan lahan pertanian ini sangat kering karena musim kemarau yang panjang. Terjadinya musim kemarau yang panjang, menyebabkan lahan menjadi gersang (Gambar 4). Lahan pertanian ini memanfaatkan sungai irigasi untuk pengairan. Sungai itu pula yang dimanfaatkan masyarakat untuk memenuhi kebutuhan air sehari-hari seperti mandi dan mencuci. Apabila sungai itu kering maka masyarakat harus membeli air.

Kekeringan juga dapat diakibatkan oleh tidak adanya pohon yang dapat menyimpan cadangan air pada musim kemarau. Lahan pertanian di lokasi penelitian sangat gersang pada musim kemarau. Pada musim penghujan, banjir kerap terjadi di lahan pertanian yang bersebelahan langsung dengan saluran irigasi. Untuk itu penanaman pohon sangat penting untuk dilakukan, selain untuk menyimpan cadangan air, pohon juga dapat mencegah banjir.

\section{Pertambakan}

Di Sawah Luhur, perikanan air payau atau pertambakan memiliki luas sekitar 515 ha (Monografi Desa Sawah Luhur 2008) yang terpusat dari wilayah bibir pantai sampai jalan raya dan pemukiman penduduk. Hak milik lahan pertambakan sudah bukan menjadi milik warga setempat, mereka hanya sebagai penggarap. Berdasarkan Gambar 5 terlihat kondisi tambak yang sangat gersang. Pada musim kemarau, air tambak mengering, pohon pelindung (lamtoro) dan semak belukar di sekitar tambak juga ikut mengering. Banyak tumbuhan yang ada di tengah tambak ditebang. Pada saat kondisi seperti ini tambak sudah tidak difungsikan lagi, dan akan difungsikan kembali pada musim penghujan.

\section{Tambak tumpangsari}

Tambak tumpansari (silvofishery) merupakan pola pemanfaatan hutan mangrove yang dikombinasikan dengan tambak/empang (Dewi 1995). Sebagian tambak di Sawah Luhur sudah difungsikan sebagai tambak tumpangsari, yang tersebar di wilayah pesisir pantai dengan luas sekitar 20 ha. Sebagian besar tambak tumpangsari tersebut dikelola oleh WIIP. Kondisi tanaman tambak tumpangsari yang dikelola oleh WIIP tersebut sudah berumur sekitar 2 tahun, dengan ketinggian pohon rata-rata 1 meter. Tanaman mangrove yang berada di tambak tersebut mayoritas jenis Rhizophora spp. (Gambar 6.A). Terdapat pula beberapa tambak tumpangsari yang dikelola oleh masyarakat salah satunya terletak dekat dengan wilayah buffer zone (Gambar 6.B). Tanaman mangrove yang berada di tambak masyarakat mayoritas jenis Avicennia alba yang sudah berumur lebih dari 10 tahun. Tanaman mangrove ini merupakan tanaman yang masih dipertahankan dan dijaga oleh pemilik tambak.

\section{Cagar alam}

Pada awalnya kawasan Pulau Dua atau yang dikenal oleh masyarakat dengan sebutan "Pulau Burung" memiliki luas 8 ha dan lokasinya terpisah dari Pulau Jawa. Namun adanya sedimentasi yang cukup tinggi, dibawa oleh arus laut perairan Teluk Banten menyebabkan terjadinya tanah timbul di sekitar kawasan ini. Pada akhir tahun 1970-an, Pulau Dua menyatu dengan daratan Pulau Jawa. Menyadari perkembangan adanya tanah timbul dan kemajuan pembangunan serta tekanan penduduk yang semakin meningkat, maka untuk melindungi kawasan ini Pemerintah Indonesia pada tahun 1984 melalui Surat Keputusan Menteri Kehutanan Nomor 253/Kpts/II/1984, menetapkan bahwa tanah timbul yang berada di sebelah selatan Pulau Dua menjadi tanah cagar alam sehingga kawasan cagar alam ini memiliki luas 30 ha. Jenis tumbuhan yang terdapat pada kawasan ini, antara lain: kepuh, ketapang, api-api, dadap, cangkring dan pace. Kawasan ini juga menjadi habitat burung air, dan pada musim-musim tertentu menjadi tempat persinggahan dan berkembang biak beberapa jenis burung migran (Gambar 7).

\section{Buffer zone}

Buffer zone merupakan daerah yang berbatasan langsung antara bibir pantai dan daratan. Daerah ini harus memiliki daerah perlindungan yang berhutan. Hal ini dimaksudkan untuk melindungi daerah sekitar pantai terhadap adanya abrasi, pasang rob, dan tsunami. Pada Perda Kota Serang No. 6 Tahun 2011 belum terdapat ketentuan khusus mengenai wilayah buffer zone. Untuk menjaga keamanan dan kestabilan lingkungan, seharusnya di wilayah pesisir Sawah Luhur harus memiliki batasan buffer zone untuk mencegah terjadinya abrasi pantai.

Berdasarkan Gambar 8 hanya sebagian kecil di wilayah buffer zone yang ditumbuhi mangrove, dengan umur berkisar antara 2-3 tahun. Sebelumnya di wilayah buffer zone sudah pernah dilakukan penanaman mangrove oleh beberapa LSM, namun keberhasilan penanamannya masih rendah. Hal ini dikarenakan adanya abrasi pantai, yang selalu menghanyutkan tanaman muda. Geomorfologi pantai yang datar dan pendek merupakan salah satu faktor yang menyebabkan wilayah ini sangat penting untuk dilakukan penanaman. 


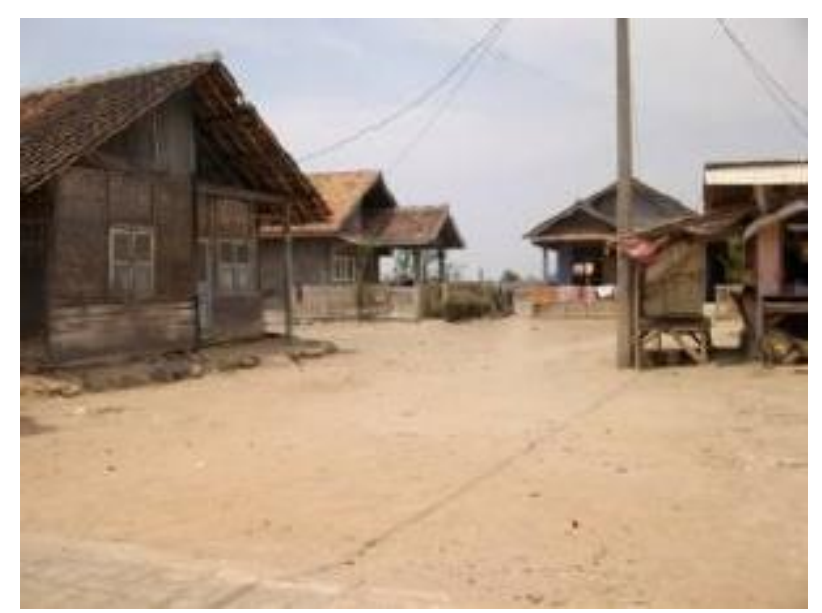

Gambar 3. Kondisi pemukiman Desa Sawah Luhur, Kota Serang, Banten

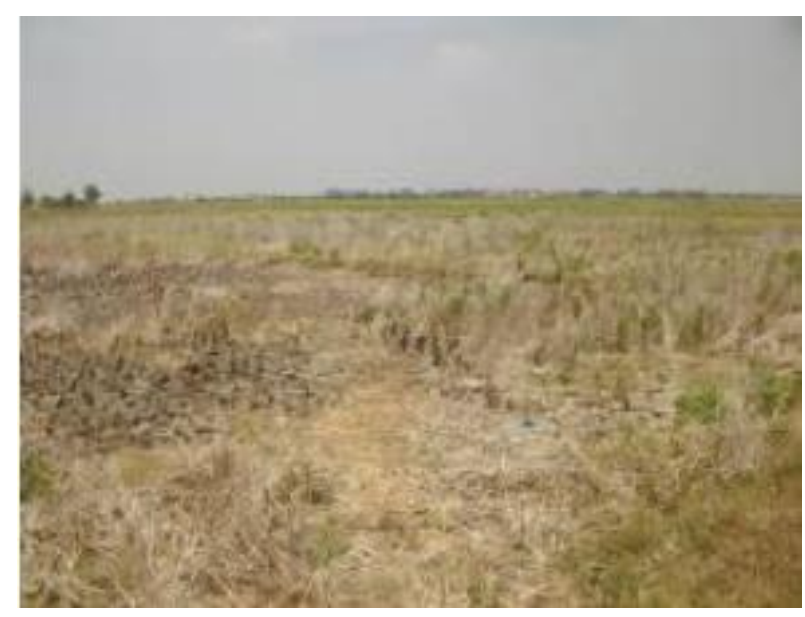

Gambar 4. Kondisi lahan pertanian di Desa Sawah Luhur, Kota Serang, Banten

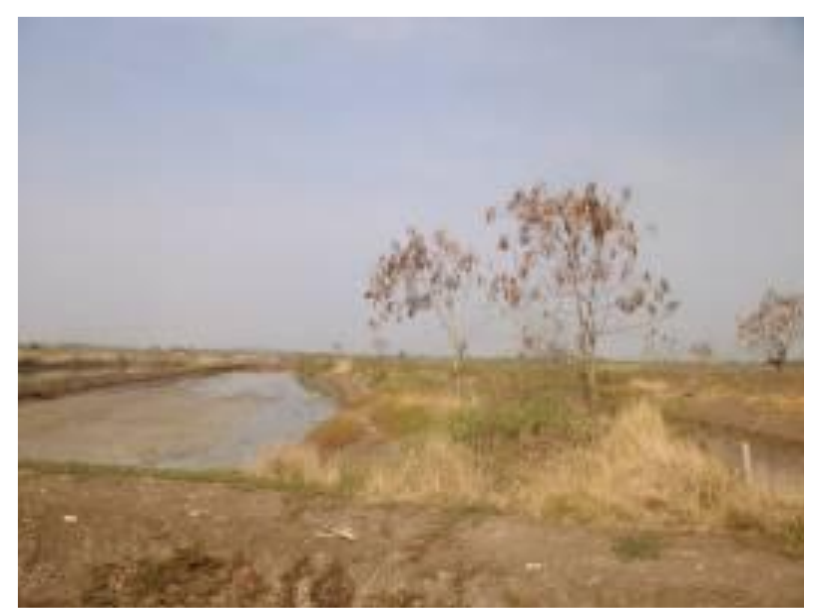

Gambar 5. Kondisi lahan pertambakan masyarakat Desa Sawah Luhur, Kota Serang, Banten.

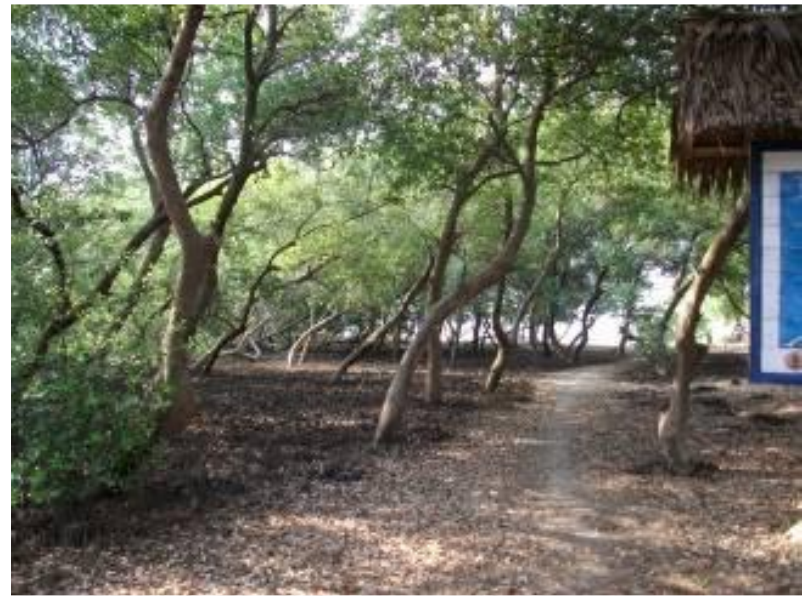

Gambar 7. Kondisi Cagar Alam Pulau Dua terletak di tepi pantai yang didominasi oleh Avicennia spp.

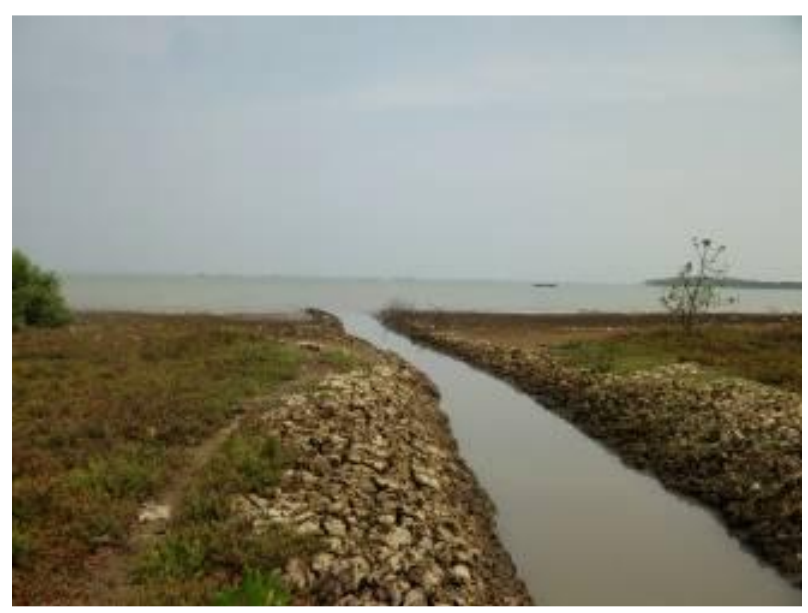

Gambar 8. Wilayah buffer zone tanpa vegetasi di wilayah jalur hijau Desa Sawah Luhur, Kota Serang, Banten.

\section{Pengairan dan sungai}

Pada musim kemarau, seluruh dusun di Desa Sawah Luhur mengalami kekeringan. Bahkan pada musim penghujan pun masyarakat masih kesulitan mendapatkan air bersih. Pada Gambar 9.A terlihat masyarakat Dusun Kacancang memanfaatkan sumber air satu-satunya di dusun mereka. Air tersebut tidak layak untuk digunakan, tetapi masyarakat sudah tidak punya pilihan lain, hanya sumber air itulah yang dapat masyarakat manfaatkan. Sementara itu, masyarakat yang tinggal di Dusun Cangkring, Badamussalam, dan Cangkring sebagian besar memanfaatkan air sungai irigasi (Gambar 9.B) yang sangat kotor untuk dijadikan mandi, mencuci, dan lain-lain, karena hanya sungai itu yang dapat memenuhi kebutuhan air. Masyarakat saat ini membutuhkan bantuan dari pemerintah dan pihak luar berupa air bersih. 


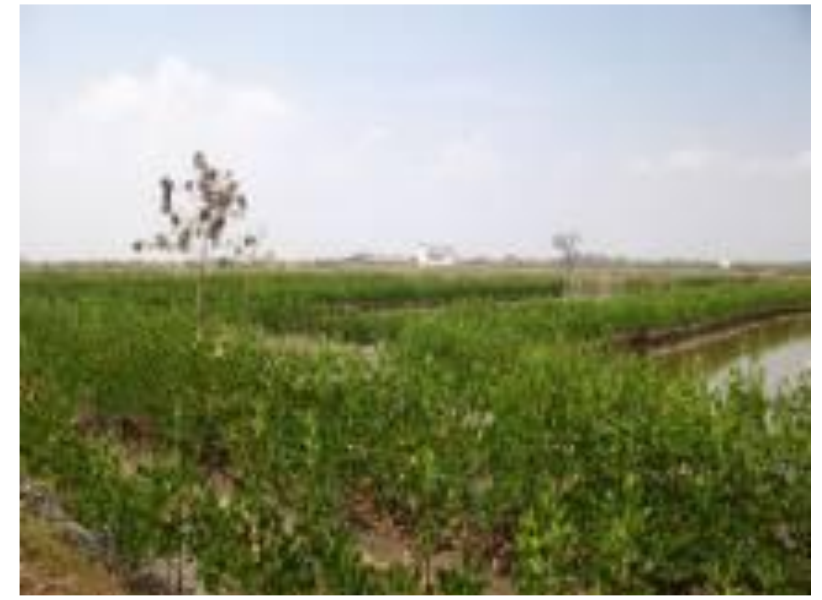

A

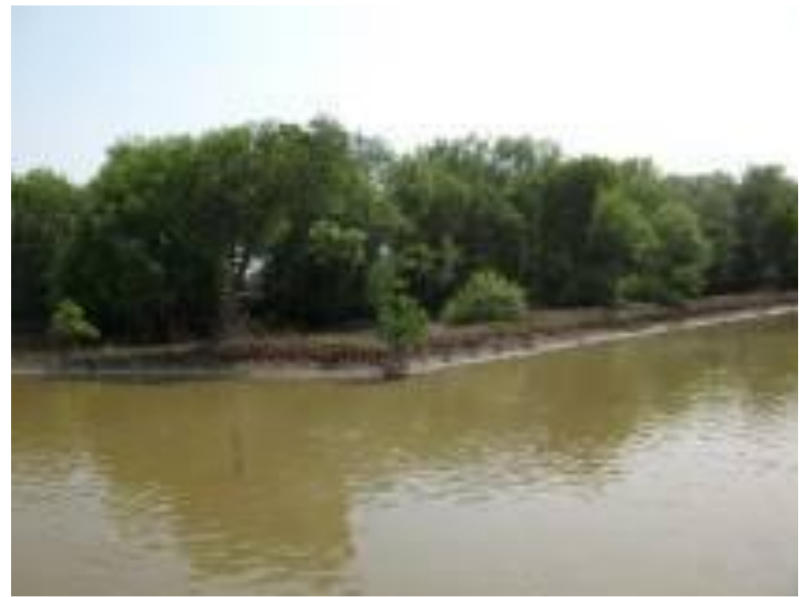

B

Gambar 6. Kondisi lahan pertambakan tumpangsari. A. Tambak tumpangsari yang dikelola oleh WIIP, B. yang dikelola oleh masyarakat

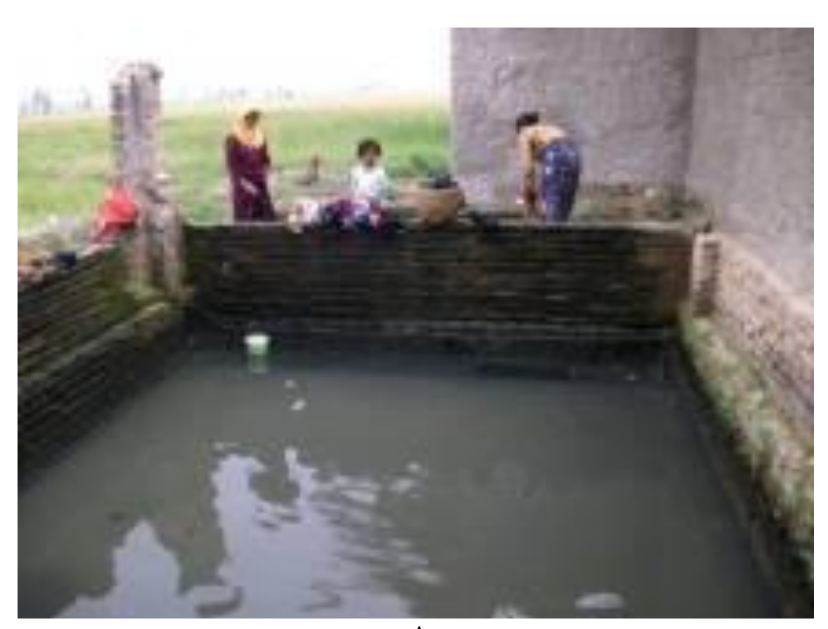

$\mathbf{A}$

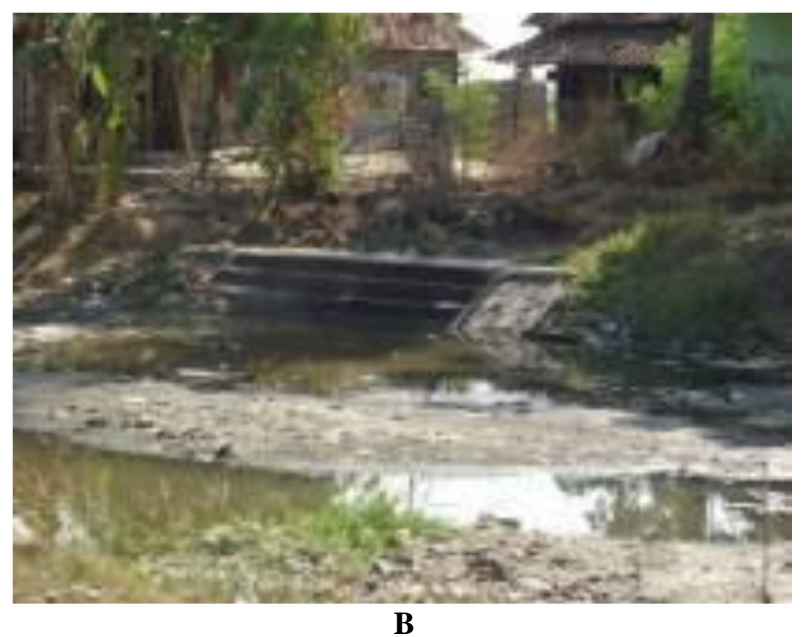

B

Gambar 9 Kondisi sumber air dan sungai irigasi di Desa Sawah Luhur, Kota Serang, Banten. A. Sumber air dari mata air di Dusun Kecancang, B. Sungai Irigasi yang mengering di Desa Sawah Luhur, Kota Serang, Banten

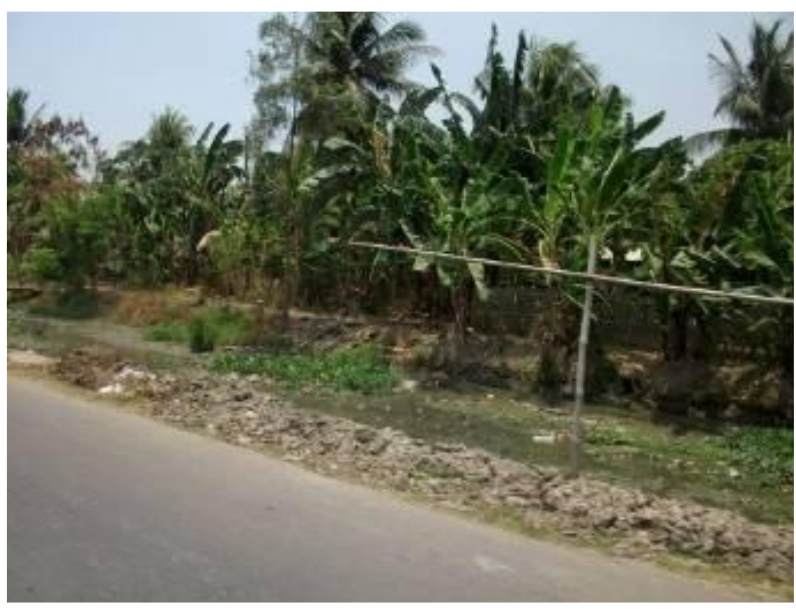

$\mathbf{A}$

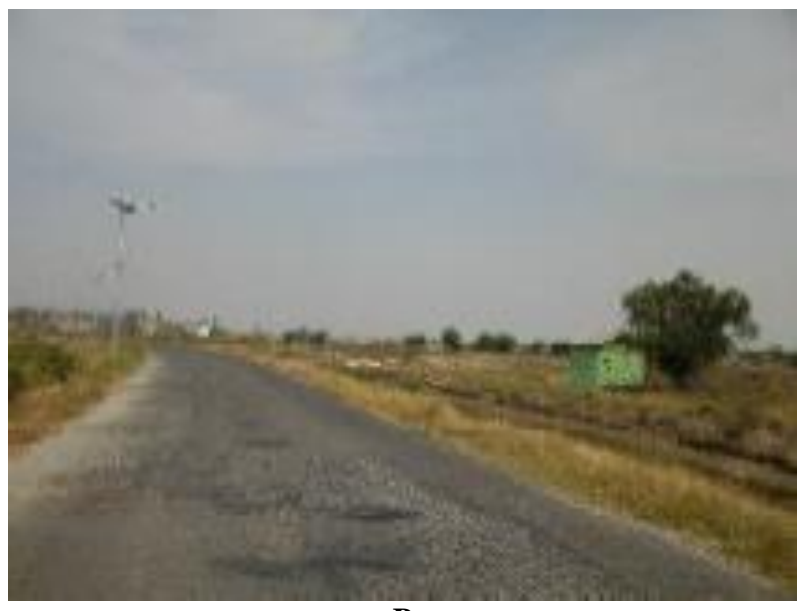

B

Gambar 10 Jalan raya di Desa Sawah Luhur, Kota Serang, Banten. A. Jalan yang terkena dampak luapan dari sungai irigasi, B. Jalan yang terkena dampak luapan pasang rob 


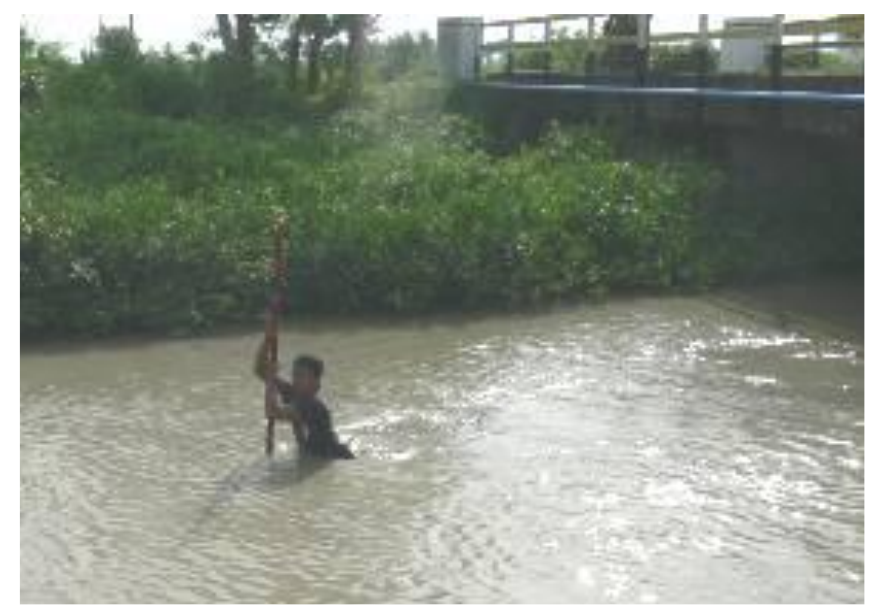

Gambar 11 Pengukuran pasang surut di Sungai Padek, Desa Sawah Luhur, Kota Serang, Banten.

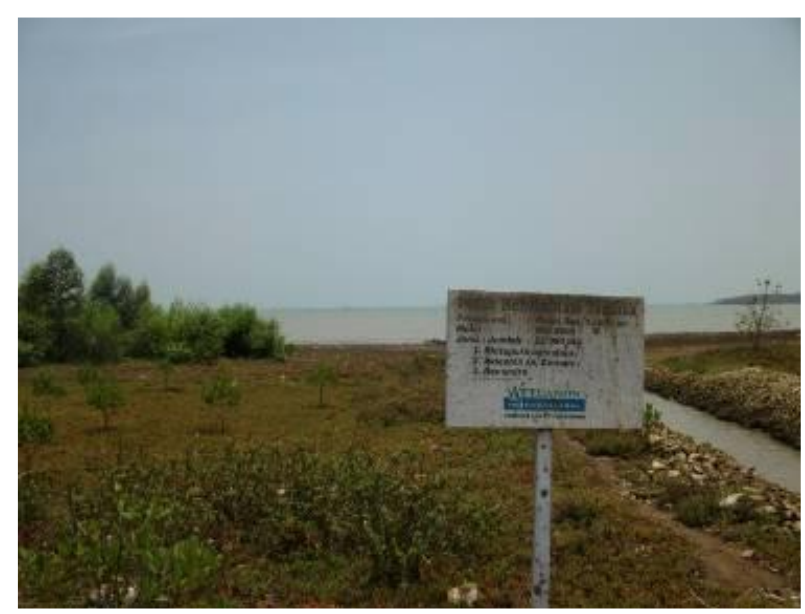

Gambar 12 Wilayah buffer zone yang terkena dampak abrasi.

\section{Jalan raya}

Jalan raya di Sawah Luhur terletak berbatasan dengan daerah pemukiman, pertambakan dan pertanian. Kondisi jalan yang berada di tiga lokasi ini sudah baik, tetapi jalan yang berada di dekat lahan pertanian dan pemukiman sering terkena luapan air yang berasal dari sungai irigasi. Pada Gambar 10.A terlihat sungai yang berada di pinggir jalan sudah mengalami pendangkalan dan banyak terdapat enceng gondok serta sampah. Selain itu diperparah dengan tidak adanya tanaman di pinggir jalan raya. Untuk jalan raya yang bersebelahan dengan lahan pertambakan (Gambar 10.B) pernah mengalami banjir rob yang diakibatkan oleh air pasang. Banjir ini dikhawatirkan dapat mempengaruhi umur dan kualitas jalan.

\section{Tanah/lumpur dan air}

Berdasarkan survei lapangan seluruh lokasi Sawah Luhur memiliki peluang yang cukup tinggi untuk penanaman mangrove. Substrat yang berlumpur serta adanya genangan merupakan dua parameter yang dapat dijadikan alasan untuk penanaman mengrove. Meskipun demikian, terdapat dua pembatas yakni terlalu lembutnya substrat lumpur didasar tambak dan salinitas yang terlalu tinggi di beberapa tambak. Terlepas dari faktor pembatas tersebut, penanaman mangrove masih sangat memunginkan untuk dilakukan. Untuk menghadapi kondisi substrat lumpur, penanaman sebaiknya menggunakan jenis mangrove yang berpropagul panjang, misalnya Rhizophora mucronata.

\section{Jangkauan pasang surut}

Pasang surut air laut merupakan fenomena yang diartikan sebagai naik turunnya muka laut secara berkala akibat adanya gaya tarik benda-benda angkasa terutama matahari dan bulan terhadap massa air di bumi (Pariwono 1989). Menurut keterangan petani tambak, pasang surut bisa terjadi dua kali dalam sehari, yakni: pasang siang dan malam hari. Tetapi pada akhir-akhir ini yakni pada bulan September dan Oktober jarang terjadi pasang air laut. Hal ini bertentangan dengan pendapat Wyrtki (1961) yang menyebutkan Pasang surut di wilayah Jawa Barat (Pantai Utara Jawa), jenis pasang surut yang terjadi adalah pasang surut campuran condong harian tunggal (Mixed Tide, Prevailing Diurnal) yakni pasang surut yang setiap harinya terjadi satu kali pasang dan satu kali surut tetapi terkadang dengan dua kali pasang dan dua kali surut yang sangat berbeda dalam tinggi dan waktu. Hal ini membuktikan bahwa keadaan waktu pasang surut sudah mengalami perubahan yang dapat terjadi akibat adanya perubahan iklim. Pasang surut air laut sangat mempengaruhi kegiatan para petambak. Petambak Sawah Luhur bergantung pada kondisi cuaca. Pada saat pasang, masyarakat akan memasang bubu untuk menangkap udang. Apabila air surut. masyarakat akan mengalami kesulitan mendapatkan air untuk pengairan tambak.

Pengukuran pasang surut air laut telah dilakukan di Sawah Luhur, Teluk Banten dilakukan selama 2 kali 24 jam pada tanggal 15 Januari 2010. Hasil perbandingan antara penghitungan pasang surut in situ di Sungai Padek dengan prediksi pasang surut dari Pelabuhan Suralaya (25 $\mathrm{km}$ dari Sawah Luhur) secara umum serupa, karena berada pada posisi yang sama di pesisir utara yang dipengaruhi oleh Laut Jawa (Gambar 11).

\section{Tingkat abrasi}

Erosi pantai atau abrasi merupakan ancaman serius yang perlu diperhatikan dalam pelaksanaan penanaman mangrove, terutama di daerah bibir pantai. Berdasarkan pengamatan di lapangan, telah terjadi abrasi di wilayah buffer zone. Setelah dilakukan penanaman Rhizophora spp. dan Avecennia spp., di lokasi buffer zone, pada tahun 2007, maka sebagian telah hilang karena terkena abrasi. Wilayah ini memang rawan abrasi, karena bentuk geomorfologi pantai yang pendek dan sempit. Di wilayah buffer zone sangat penting dilakukan penanaman mangrove, terutama untuk mencegah terjadinya abrasi, dan melindungi daerah sekitarnya (Gambar 12).

\section{Salinitas air laut}

Pengukuran salinitas air sumur warga telah dilakukan pada Januari 2010 di tiga dusun di Desa Sawah Luhur, yaitu: Dusun Kebon Baru, Dusun Cangkring dan Dusun Badamussalam (Tabel 1). 
Tabel 1. Nilai salinitas pada berbagai kedalaman sumur dan jarak dari garis pantai

\begin{tabular}{ccc}
\hline $\begin{array}{c}\text { Jarak dari garis } \\
\text { pantai }(\mathbf{k m})\end{array}$ & $\begin{array}{c}\text { Kedalaman pengambilan } \\
\text { sampel air }(\mathbf{m})\end{array}$ & $\begin{array}{c}\text { Salinitas } \\
(\mathbf{p p t})\end{array}$ \\
\hline 2,5 & 8 & 8 \\
4 & 16 & 11 \\
4 & 140 & 1,5 \\
\hline
\end{tabular}

Sumber: Wetlands International Indonesia Programme (WIIP, kom. pri. 2011)

Nilai salinitas air untuk perairan tawar biasanya berkisar antara 0-5 ppt, perairan payau biasanya berkisar antara 6-29 ppt, dan perairan laut berkisar antara 30-35 ppt (Gusrina 2008). Dari sebaran salinitas ini dapat diketahui bahwa intrusi air laut telah mencapai $4 \mathrm{~km}$ ke arah darat dan kecenderungan intrusi terjadi pada daerah pemukiman yang padat penduduk. Hal ini dapat dijelaskan bahwa akibat pemanfaatan air dalam tanah yang berlebih menyebabkan tanah menjadi lebih porus sehingga memudahkan pergerakan air laut untuk masuk mengisi rongga tersebut.

\section{Intrusi air laut}

Intrusi air laut di Sawah Luhur sudah sangat parah, sehingga menyebabkan masyarakat tidak memiliki sumber air bersih yang memadai dikarenakan rasa asin pada air sumurnya. Dari ketujuh dusun di Desa Sawah Luhur, hanya Dusun Kebon Baru yang memiliki pengairan yang cukup baik. Kekeringan yang melanda Sawah Luhur mengharuskan masyarakat memanfaatkan sungai irigasi dan sumber air. Sungai irigasi dan sumber air tersebut tidak layak digunakan untuk keperluan sehari-hari, karena kotor. Secara umum masyarakat desa menggunakan air isi ulang untuk minum

Hasil pengukuran menunjukkan kadar salinitas air sumur (kedalaman sumur sekitar $8 \mathrm{~m}$ ) pada jarak sekitar 2,5 km dari garis pantai sebesar $7 \mathrm{ppt}$. Pada jarak $4 \mathrm{~km}$, salinitas air sumur dengan kedalaman $16 \mathrm{~m}$ adalah $11 \mathrm{ppt}$. Pada lokasi yang sama dari sumur artesis dengan kedalaman $140 \mathrm{~m}$ menunjukkan salinitas 1,5 ppt. Dari sebaran salinitas ini dapat diketahui bahwa intrusi telah mencapai $4 \mathrm{~km}$ ke arah darat. Kecenderungan intrusi air laut ini terjadi pada daerah yang padat penduduk. Hal ini dapat dijelaskan bahwa adanya rongga di dalam tanah memudahkan pergerakan air laut untuk masuk mengisi rongga tersebut.

Beberapa faktor-faktor yang mempengaruhi laju intrusi air laut, sebagai berikut: (i) Pengalihfungsian lahan mangrove menjadi kawasan pertambakan. Area mangrove dapat menghambat laju intrusi air laut. (ii) Pengambilan air tanah secara berlebihan mengakibatkan defisit cadangan air tanah dalam cekungan air tanah yang dipompakan ke permukaan tanah, sehingga secara alamiah akan menarik air laut. Bila air laut tidak terkompensasi ke pori-pori maka pori-pori tanah akan menjadi berongga udara yang dapat termampatkan oleh tekanan tanah dan bangunan di atasnya. Fenomena ini dikenal dengan nama penurunan permukaan tanah yang dalam skala luas yang akan memicu genangan pasang air laut di daratan (rob)

\section{Kajian jalur hijau berdasarkan sosial ekonomi Karakteristik responden}

Cara pandang masyarakat Sawah Luhur terhadap rencana penetapan jalur hijau diketahui dengan wawancara. Wawancara dilakukan terhadap 30 responden yang dikelompokkan menjadi empat kelompok, yaitu: (i) petani mangrove, (ii) masyarakat, (iii) aparat pemerintah dan (iv) pelajar (Tabel 2).

Kelompok petani mangrove merupakan kelompok bentukan salah satu LSM yang melakukan kegiatan penanaman mangrove di Sawah Luhur yang beranggotakan 6 orang; kelompok masyarakat yang melakukan aktivitas kerja di Sawah Luhur; aparat pemerintahan Desa Sawah Luhur; aparat pemerintahan Kecamatan Kasemen; petugas KSDA Cagar Alam Pulau Dua, dan aparat pemerintahan Kota Serang yakni Bappeda; serta kelompok pelajar yaitu mahasiswa dan pelajar SMA. Stakeholders yang ditunjuk masing-masing memiliki peran untuk melangsungkan adanya penetapan jalur hijau di Sawah Luhur.

Dengan adanya kerjasama antar stakeholders fungsi jalur hijau untuk mempertahankan pantai dari ancaman erosi serta untuk mempertahankan fungsi mangrove sebagai tempat berkembang biak dan berpijah berbagai jenis ikan akan dapat terlaksana dengan baik. Dalam menentukan kebijakan jalur hijau mangrove aspek ekologi dan sosial ekonomi merupakan aspek yang sangat penting dan saling berkaitan dalam menentukan suatu kebijakan jalur hijau di pesisir pantai.

\section{Kondisi sosial ekonomi masyarakat}

Lahan di Sawah Luhur saat ini banyak dimanfaatkan untuk lahan pertanian dan perikanan air payau. Pada Perda Kota Serang No. 6 Tahun 2011 disebutkan bahwa Kecamatan Kasemen, khusunya Desa Sawah Luhur ditetapkan sebagai kawasan pertanian, perikanan air payau, kawasan perlindungan setempat yang merupakan sempadan sungai dan Cagar Alam Pulau Dua atau hutan mangrove.

Pemanfaatan lahan di Sawah Luhur sebagian besar merupakan daerah pertanian sebesar 48\%, serta pertambakan sebesar 27\%. Hal ini menunjukkan sebagian besar penduduk bermata pencaharian sebagai petani sawah dan petambak. Menurut keterangan masyarakat dan aparat pemerintahan, masyarakat Sawah Luhur sebagian besar bahkan hampir seluruhnya hanya sebagai penggarap, baik di lahan pertanian, maupun pertambakan. Kepemilikan lahan di Sawah Luhur sebagian besar dimiliki orang luar Kota Serang dan pemerintah Kota Serang. Untuk pemukiman, sebagian merupakan milik pribadi, dan sebagian merupakan lahan pemerintah daerah, yang luasan keseluruhan untuk pemukiman kurang lebih $2 \%$ dari luas wilayah Sawah Luhur. Desa Sawah Luhur memiliki 8 dusun, antara lain: Dusun Kebon Lama, Kebon Baru, Kacancang, Badamussalam, Cangkring, Kebasiran, Manggarong, serta Pandek Pancur.

Desa Sawah Luhur pada tahun 2008 didiami oleh 2.122 KK dengan populasi total 7.512 jiwa, terdiri dari 3.340 jiwa laki-laki $(44,5 \%)$ dan 4.172 jiwa perempuan (55,5\%). Kepadatan penduduk Sawah Luhur adalah 397 jiwa/ $/ \mathrm{km}^{2}$ (Monografi Desa Sawah Luhur 2008). 
Tabel 2. Sebaran kelompok responden

\begin{tabular}{lll}
\hline Karakteristik responden & $\begin{array}{l}\text { Jumlah } \\
\text { (orang) }\end{array}$ & $\begin{array}{l}\text { Persentase } \\
(\mathbf{\%})\end{array}$ \\
\hline Kelompok tani mangrove & 6 & 20,00 \\
Kelompok masyarakat & 14 & 46,67 \\
Kelompok aparat pemerintahan & 8 & 26,67 \\
Kelompok pelajar & 2 & 6,67 \\
Total & 30 & 100 \\
\hline
\end{tabular}

Indikator terpenting untuk kesejahteraan ekonomi masyarakat adalah besarnya pendapatan keluarga. Dengan perolehan pendapatan yang layak, masyarakat dapat memenuhi kebutuhan hidupnya. Dalam penelitian ini, responden berasal dari petani sawah dan petani tambak, hal ini dikarenakan 70,69\% masyarakat Sawah Luhur memiliki mata pencaharian sebagai petani sawah dan petani tambak. Selain itu, responden juga memiliki keterkaitan langsung dengan wilayah pesisir yang nantinya sebagai rujukan jalur hijau. Penduduk yang bermata pencaharian dalam usaha perbengkelan sebanyak $360 \mathrm{KK}$, sementara yang berprofesi sebagai pedagang sebanyak $250 \mathrm{KK}$ (Monografi Desa Sawah Luhur 2008).

Petani di Sawah Luhur digolongkan menjadi dua yaitu petani sawah (pemilik, atau penggarap/buruh) dan petani tambak. Komoditi unggulan dari pertanian sawah di Sawah Luhur adalah padi. Hasil panen biasanya dijual kepada tengkulak dengan sistem borongan. Selain padi, komoditi lain yang dibudidayakan masyarakat adalah sayuran dan buah-buahan. Pada umumnya, hasil panen sayur dan buah dijual dengan sistem borongan dan eceran.

Jenis unggulan petani tambak di Sawah Luhur adalah ikan bandeng. Sistem penjualan hasil tambak yang umum dilakukan petani tambak adalah sistem jual per $\mathrm{kg}$ atau borongan. Selain ikan bandeng, sebagian petambak ada juga yang membudidayakan udang. Jenis udang yang umum dibudidayakan oleh petani tambak adalah udang bogo, udang air, udang api-api, dan udang peci, tetapi menurut masyarakat, saat ini sangat sulit membudiayakan udang, akibat adanya pencemaran air.

Mata pencaharian masyarakat yang mayoritas bekerja di bidang pertambakan dan perikanan hanya sebagai penggarap saja. Menurut keterangan masyarakat dan aparat pemerintahan, hampir semua petani dan petambak di Sawah Luhur hanya sebagai penggarap lahan orang lain. Lahan tambak yang saat ini menjadi penopang kehidupan masyarakat sudah tidak produktif, karena tercemarnya air yang masuk ditambak, sehingga hasil yang didapat sangat kurang, baik untuk harian, maupun musim panen. Masyarakat yang bekerja di wilayah tambak, untuk mencukupi kehidupan sehari-harinya, mereka memasang bubu untuk mendapatkan udang pada saat terjadi air pasang laut.

Berdasarkan keterangan masyarakat pendapatan ratarata dari hasil tangkapan bubu berkisar antara Rp. 25.000 sampai Rp. 50.000, namun pada musim kemarau sangat sulit untuk mendapatkan penghasilkan dari memasang bubu. Seiring dengan berjalannya waktu, pencemaran dan kerusakan lingkungan mengakibatkan semakin turunnya produktivitas tambak, sehingga pendapatan yang dihasilkan oleh petambak juga menurun. Untuk meningkatkan produktivitas lahan tambak perlu dilakukan rehabilitasi lingkungan, salah satu caranya dengan dilakukan penanaman mangrove. Seperti diungkapkan oleh Kusmana (2003) mangrove merupakan tempat hidupnya berbagai biota laut, ikan, dan udang sebagai penyaring dan pengurai bahan-bahan organik yang berasal dari daratan.

\section{Kondisi sumber air}

Selain sulitnya untuk memenuhi kabutuhan ekonomi, masyarakat Sawah Luhur juga sulit mendapatkan air bersih. Sumur yang ada saat penelitian ini, sudah tidak berfungsi lagi, pada musim kemarau tidak ada air sama sekali, dan ketika musim hujan air tersebut asin karena intrusi air laut. Air terutama digunakan untuk mandi, mencuci dan minum. Berdasarkan hasil wawancara terhadap masyarakat, kualitas air sumur terbilang payau. Hal ini sama halnya pada penelitian yang dilakukan oleh WIIP (kom pri., 2011) terhadap salinitas air sumur yang menyebutkan bahwa salinitasnya menunjukkan kadar payau. Untuk air sungai, masyarakat menyebutkan kualitasnya sangat buruk, yaitu keruh, payau, dan berbau (Gambar 9; Gambar 13). Bila tersedia maka air sumur dan sungai sama-sama digunakan untuk mandi, sedang untuk mencuci masyarakat lebih mengandalkan air sungai. Adapun untuk minum mereka membeli air bersih (Gambar 14)

Gambar 9.A merupakan satu-satunya sumber air yang berada di Dusun Kecancang. Sumber air tersebut sangat keruh dan berbau. Masyarakat sudah terbiasa dengan air yang seperti itu, selain kotor, menurut masyarakat air tersebut juga sudah terkena dampak intrusi air laut. Rasa asin dan keruh menyebabkan sumber air tersebut hanya dimanfaatkan untuk mencuci dan mandi. Sedangkan untuk kebutuhan memasak dan minum, masyarakat harus membelinya.

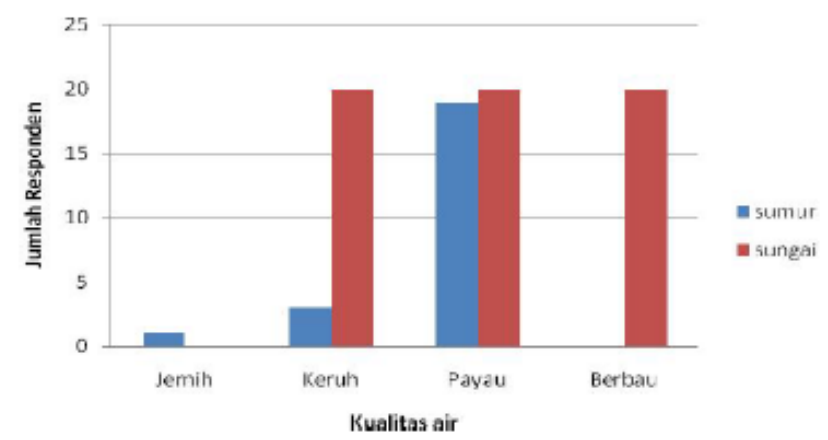

Gambar 13 Kualitas sumber air di Desa Sawah Luhur, Kota Serang, Banten

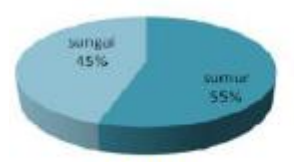

(a) Mandi

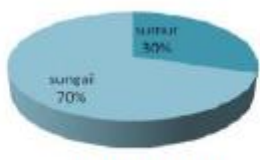

(b) Mencuci

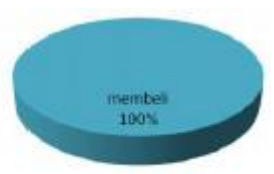

(c) Minum
Gambar 14. Pemanfaatan air untuk kebutuhan sehari-hari berdasarkan jumlah responden masyarakat 
Gambar 10 merupakan sungai irigasi yang mengalir di sepanjang jalan Desa Sawah Luhur. Sungai ini sangat bermanfaat bagi masyarakat, meskipun kondisi air yang sangat tidak layak untuk digunakan. Air sungai irigasi sudah tercemar, kotor, dan berbau. Tetapi kenyataanya masyarakat sangat bergantung dengan air sungai ini. Terlihat pada Gambar 9.B, sungai irigasi dimanfaatkan untuk mencuci, mandi. Pada musim kemarau, sungai ini kering. Jika sungai ini kering masyarakat harus rela menyisihkan uang mereka untuk membeli, bahkan menurut masyarakat, ada yang harus mencari air ke tempat lain, karena mereka tidak mampu untuk membeli air.

\section{Persepsi terhadap perubahan ekosistem dan iklim}

Ekosistem mangrove memiliki peranan yang sangat penting bagi lingkungan pesisir, baik dari segi fisik, ekologis, dan ekonominya. Oleh karena nilai sosial ekonominya, maka ekosistem mangrove banyak dimanfaatkan dan dikonversi untuk berbagai keperluan (DKP 2007). Konversi ini memicu terjadinya kerusakan yang sudah terlihat di wilayah pesisir Sawah Luhur. Menurut masyarakat terdapat beberapa jenis tanaman, ikan, hewan dan burung yang saat ini sulit untuk ditemukan.

Berdasarkan keterangan masyarakat, penyebab utama semakin sulitnya jenis tanaman, ikan dan burung sulit ditemukan adalah adanya kerusakan habitat di wilayah pesisir Sawah Luhur (Gambar 15). Kerusakan habitat ini diakibatkan oleh faktor alam dan faktor manusia. Kerusakan hutan mangrove dan konversi hutan untuk dijadikan tambak atau pengguna lainnya akibat adanya perkembangan penduduk akan menimbulkan bahaya intrusi air laut dari laut ke arah daratan (Hanson dan Koesoebiono 1977). Untuk itu pemanfaatan lahan yang bijaksana sangat perlu diperhatikan terutama utnuk ditanamani mangrove. Karena mangrove memiliki pernanan yang sangat besar. Seperti yang diungkapkan oleh Kusmana (2003) Peranan mangrove terhadap kelangsungan proses ekologis dan penyangga kehidupan yaitu: Menjaga garis pantai dan tebing dari erosi/ abrasi agar tetap stabil, mempercepat perluasan lahan, mengendalikan intrusi air laut, melindungi daerah di belakang mangrove dari hempasan gelombang dan angin kencang, mengolah limbah organik, tempat mencari makan, tempat hidup dan tempat berkembang biak berbagai jenis ikan, udang, kerang dan biota laut lainnya, tempat bersarang berbagai jenis satwa liar dan burung, serta sumber plasma nutfah.

Perubahan iklim adalah perubahan unsur-unsur iklim dalam jangka waktu panjang (50-100 tahun) yang dipengaruhi oleh kegiatan manusia yang menghasilkan emisi gas rumah kaca (GRK). Pada umumnya masyarakat Sawah Luhur kurang paham apa yang disebut dengan perubahan iklim bahkan mendengar namanya saja sudah sangat asing bagi mereka. Untuk itu mereka tidak memilih perubahan iklim sebagai salah satu faktor terjadinya perubahan ekosistem di wilayah Sawah Luhur (Gambar 16).

Berdasarkan wawancara dengan masyarakat, sebagian besar responden yang mengetahui maksud dari perubahan iklim adalah yang berasal dari aparat pemerintah daerah, pelajar, dan masyarakat kelompok tani mangrove. Hal ini disebabkan karena kurangnya penyuluhan kepada masyarakat Sawah Luhur akibat dampak dari terjadinya perubahan iklim di Sawah Luhur. Salah satu gejala adanya perubahan iklim adalah semakin tidak teraturnya musim yang terjadi, seperti pada saat ini musim kemarau yang terjadi sangat kering, dan lama. Hal ini mengakibatkan masyarakat sangat sulit untuk mencari nafkah dari hasil tambak dan laut. Perubahan pola curah hujan semacam ini sudah mulai terasa di pantai utara Jawa. Hal in juga telah dibuktikan, menurut hasil analisa yang dilakukan oleh BMKG, awal musim sudah mengalami perubahan. Di beberapa wilayah, masuknya awal musim sudah semakin mundur. Di beberapa wilayah lain semakin maju. Selain itu, perubahan yang terjadi adalah kenaikan curah hujan yang cukup tinggi pada musim hujan semakin tinggi dan lama musim kemarau semakin panjang khususnya di beberapa daerah seperti pantai utara Banten hingga Jawa Tengah.

Selain itu juga masyarakat sangat sulit mendapatkan air. Perubahan ini terjadi di Sawah Luhur, menurut masyarakat, dahulu pada tahun 1970an Sawah Luhur hasil tambak sangat bagus berbeda dengan hasil pada masa saat ini, selain itu juga air bersih mudah untuk mendapatkannya sekarang sangat sulit baik untuk keperluan minum, memasak, mandi, mencuci, serta pengairan di lahan pertanian maupun pertambakan.

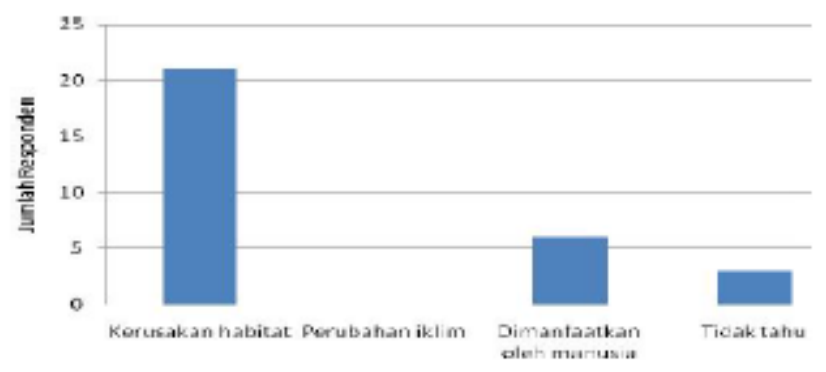

Gambar 15. Penyebab terjadinya jenis tanaman, ikan, hewan dan burung sulit ditemukan berdasarkan responden

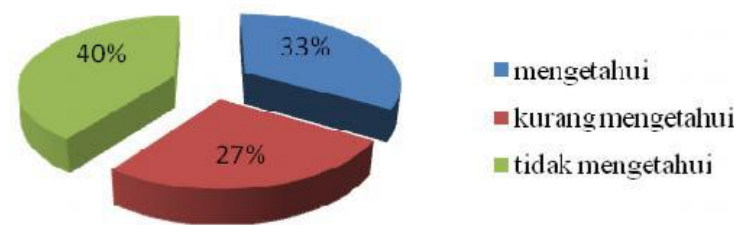

Gambar 16. Persentase pemahaman responden terhadap perubahan iklim

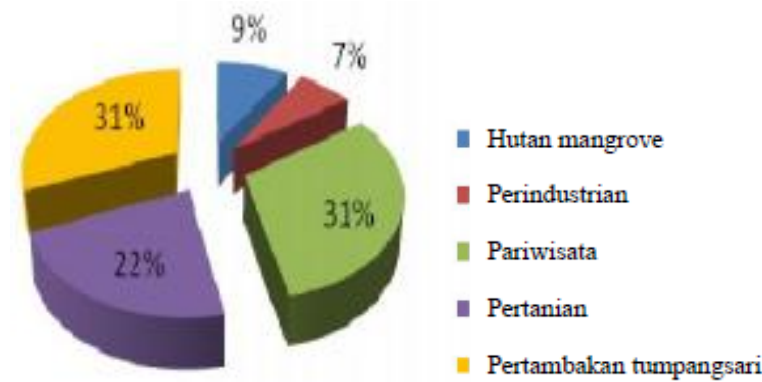

Gambar 17. Persentase persepsi responden terhadap pemanfaatan lahan 
Persepsi terhadap kebijakan jalur hijau dan pemanfaatan lahan

Persepsi masyarakat Sawah Luhur terhadap jalur hijau sangat penting untuk dipertimbangkan dalam menentukan kebijakan terhadap pengelolaan secara bijaksana di wilayah pesisir pantai. Karena masyarakat memberikan peran penting terhadap keberlanjutan kelestarian lingkungan pesisir. Kerusakan habitat yang salah satunya diakibatkan oleh kegiatan manusia karena nilai sosial ekonominya, maka ekosistem mangrove banyak dimanfaatkan dan dikonversi untuk berbagai keperluan (DKP 2007).

Berdasarkan hasil wawancara terhadap 30 responden, $100 \%$ yang berpendapat bahwa kebijakan jalur hijau perlu dilaksanakan di pesisir pantai Sawah Luhur. Seperti yang diungkapkan oleh salah satu responden yaitu pihak pengelola Cagar Alam Pulau Dua mengatakan bahwa kebijakan jalur hijau memang sudah ada ketetapannya, akan tetapi belum terlaksana dengan baik dilapangan, karena masyarakat memanfaatkan wilayah tersebut untuk pertambakan. Apabila di wilayah pesisir Sawah Luhur terdapat jalur hijau maka Cagar Alam dapat terlindungi dengan baik. Menurut masyarakat Sawah Luhur yang berprofesi sebagai petambak, mereka setuju dengan diadakannya jalur hijau, tetapi harus tetap mempertahankan tambak yang sudah ada, karena dari tambaklah mereka dapat menghasilkan uang. Pentingnya akan adanya penanaman mangrove di wilayah pesisir pantai sudah mulai dirasakan oleh masyarakat Sawah Luhur yang setiap harinya bekerja di wilayah pesisir.

Berdasarkan keterangan masyarakat Sawah Luhur beberapa yang menyebutkan pada tahun 1970an wilayah Sawah Luhur memiliki hutan mangrove yang sangat baik. Telah terjadi perubahan pemanfaatan lahan, menjadi lahan pertanian, pertambakan, dan pemukiman. Seiring dengan perubahan zaman, pendapatan masyarakat di bidang pertambakan yang sangat kurang, akibat terjadinya pencemaran air, dan fasilitas pengairan yang sangat buruk. Masyarakat sudah mulai resah dengan hal ini, dampak yang terjadi tidak hanya di wilayah desa yang dekat dengan bibir pantai, tetap juga wilayah pertanian Sawah Luhur. Fasilitas pengairan yang sangat buruk menyebabkan sulit dalam mendapatkan air bersih, baik untuk melakukan kegiatan sehari-hari, ataupun pengairan sawah.

Seperti halnya yang diungkapakan oleh Direktorat Tata Guna Tanah (1973), pertambahan penduduk mengakibatkan permintaan lahan meningkat. Lahan bermutu baik menjadi sasaran utama, dan bila lahan tersebut telah habis maka terpaksa akan digarap lahan marginal, seperti halnya pada lahan hutan mangrove yang sering menimbulkan kerugian. Alihguna laha marginal secara terus menerus tanpa pengelolaan, pengendalian dan usaha konservasi yang baik, akan menimbulkan kerusakan lingkungan, akibatnya akan terjadi kerusakan lingkungan yang akan bertambah parah, termasuk kerusakan akibat intrusi.

Berdasarkan persepsi responden terhadap pemanfaatan lahan masyarakat lebih memilih penggunaan lahan di wilayah pesisir sebagai pertambakan tumpangsari dan pariwisata, disamping akan dilakukan penanaman guna keberlangsungan air di desa, juga akan memperindah desa, dengan dijadikannya pariwisata alam (Gambar 17).

Berdasarkan keterangan aparat pemerintah desa dan kecamatan yang menyadari akan produktivitas lahan tambak menurun, mereka menginginkan adanya perubahan penggunaan lahan. Adanya tawaran investor akan mengadakan galangan kapal di Sawah Luhur, aparat pemerintah baik dari desa, kecamatan, dan Kota Serang, sangat terbuka dengan tawaran ini. Menurut pandangan mereka dengan masuknya perindustrian ke Sawah Luhur akan menjadikan Sawah Luhur lebih maju dan menambah pendapatan masyarakat dan daerah.

Pada dasarnya suatu daerah dalam melakukan pengembangan wilayah untuk dijadikan suatu perindustrian, harus dilakukan penelitian terlebih dahulu berdasarkan lingkungan dan kehidupan masyarakat. Menurut penelitian yang berkaitan dengan lingkungan menunjukkan di Sawah Luhur sudah terjadi kerusakan lingkungan sepeti intrusi air laut, abrasi, pasang rob, serta kekeringan. Untuk itu perlu dikaji ulang, bahwa galangan kapal kurang relevan apabila dibangun di wilayah pesisir Sawah Luhur.

\section{Parameter dalam penetapan jalur hijau \\ Habitat (Cagar Alam Pulau Dua)}

Sebagaimana Predikat Pulau Dua yang disebut sebagai Pulau Burung, pulau ini merupakan habitat berbagai macam burung. Untuk itu wilayah ini sangat penting dijaga untuk kelangsungan kehidupan burung. Selain itu dengan luas cagar alam 30 ha, dan jumlah burung yang sangat banyak, sangat memungkinkan burung- burung ini tidak dapat bertahan hidup akibat luasan habitat yang kurang memadai. Untuk itu perlu dilakukan penanaman mangrove sebagai daerah penyangga sebagai tempat perlindungan makhluk hidup.

\section{Vegetasi}

Dari luas wilayah 1894 ha, Sawah Luhur hanya memiliki wilayah berhutan kurang lebih 30 ha. Untuk wilayah yang rawan bencana seperti sempadan sungai dan pantai jarang sekali terdapat tanaman mangrove. Air bersih sebagai penunjang kehidupan manusia, seakan-akan sudah sangat asing untuk bisa di peroleh di desa ini. Akibat adanya intrusi air laut hingga kurang lebih $4 \mathrm{~km}$, dan di perparah adanya musim kemarau yang panjang, membuat desa ini sangat sulit untuk mendapatkan air bersih. Hampir seluruh dusun (8 dusun) yang ada di Sawah Luhur menggunakan air isi ulang untuk konsumsi, sedangkan untuk keperluan mandi dan lain-lain masyarakat menggunakan air irigasi yang sangat tercemar dan sebagian kecil masyarakat yang membeli air bersih.

Mangrove memiliki fungsi ekologis dan ekonomis yaitu melindungi daratan dari berbagai ancaman bencana dari laut (abrasi, gelombang pasang, tsunami). Sifatnya yang dapat menyerap $\mathrm{CO}_{2}$ menyebabkan mangrove berperan meredam laju perubahan iklim global sekaligus dapat memperkecil dampak kenaikan muka air laut terhadap pemukiman. Keberadaan mangrove juga dapat mengurangi laju perembesan air laut ke daratan (intrusi air laut) 
sehingga secara tidak langsung peran tersebut turut mendukung penyediaan air bersih bagi masyarakat pesisir.

\section{Dampak kerusakan alam}

Dampak kerusakan alam yang saat ini sudah terlihat di Sawah Luhur adalah intrusi air laut, kekeringan, abrasi, dan pasang rob. kekeringan merupakan salah satu indikator dari adanya perubahan iklim yang ditunjukkan dengan pola musim kemarau yang semakin panjang dan jangka waktu musim penghujan semakin pendek dengan curah hujan yang lebih banyak. Musim kemarau yang panjang mengakibatkan kekeringan yang diperparah dengan adanya intrusi air laut yang mencapai $4 \mathrm{~km}$. Selain itu pasang surut yang saat ini sudah sulit untuk diperkirakan waktunya, berdampak pada hasil tambak masyarakat. Kerusakan lingkungan tersebut mempengaruhi ketersediaan air, baik untuk pengairan tambak dan pertanian, yang merupakan sebagai sumber mata pencaharian masyarakat.

Kerusakan hutan mangrove, dan konversi hutan untuk dijadikan tambak atau pengguna lainnya akibat adanya perkembangan penduduk akan menimbulkan bahaya intrusi air laut dari laut ke arah daratan. Menurut Hanson dan Koesoebiono (1977), praktek penggunaan lahan di wilayah pesisir jelas merugikan, diantaranya adanya penggundulan vegetasi di daratan estuaria tanpa mempertimbangkan keberadaan vegetasi yang berperan penting bagi produsen primer perairan. Kerusakan sebagian atau seluruh vegetasi pantai tanpa kesadaran akan pentingnya jalur hijau, juga akan menimbulkan bahaya intrusi air.

\section{Keadaan masyarakat}

Potensi besar yang dimiliki kawasan peisisir pantai memungkinkan pemanfaatan yang besar-besaran oleh masyarakat. Terutama pemanfaatan lahan untuk bertambak. Pemerintah kota Serang juga berencana membuat galangan kapal di Sawah Luhur. Selain itu juga di kawasan pesisir memiliki daya dukung dalam bidang pariwisata. Potensi besar yang dimiliki tersebut dapat menimbulkan ancaman perubahan iklim yang nantinya bisa menimbulkan bencana apabila wilayah pesisir tidak dilakukan pengelolaan secara terpadu.

Mata pencaharian masyarakat yang mayoritas sebagai petani dan petambak sangat bergantung pada pemanfaatan lahan. Untuk itu pemerintah harus bijaksana dalam mengambil keputusan agar masyarakat masih dapat bekerja dengan baik, serta lingkungan masih tetap terjaga. Dengan adanya kebijakan pengelolaan wilayah pesisir pantai terpadu. Seperti halnya yang diungkapakan oleh Soewito 1982 Lebar hutan mangrove untuk jalur hijau yang seyogyanya disesuaikan dengan kondisi pantai setempat dan harus mamperhitungkan kelestarian lingkungan dan ekonomi.

\section{Solusi penetapan jalur hijau}

Berdasarkan hasil kajian terhadap kebijakan jalur hijau sesuai Keppres No. 32 Tahun 1990 maka lebar jalur hijau yang diperuntukkan untuk Sawah Luhur adalah $91 \mathrm{~m}$. Apabila di wilayah pesisir Sawah Luhur hanyadilakukan penanaman pada area yang sudah ditetapkan oleh Keppres No. 32 Tahun 1990 saja, maka kurang bijaksana. Pasalnya setelah dilakukan kajian terhadap keadaan biofisik di Sawah Luhur, di wilayah tersebut telah terjadi intrusi air laut mencapai $4 \mathrm{~km}$ yang mengakibatkan masyarakat kesulitan untuk mendapatkan air bersih dan terjadinya banjir pasang yang pernah mencapai ke pemukiman dan jalan raya dengan jarak $\pm 2 \mathrm{~km}$ dari laut. Berikut ini merupakan gambaran penerapan jalur hijau mangrove di Sawah Luhur (Gambar 18).

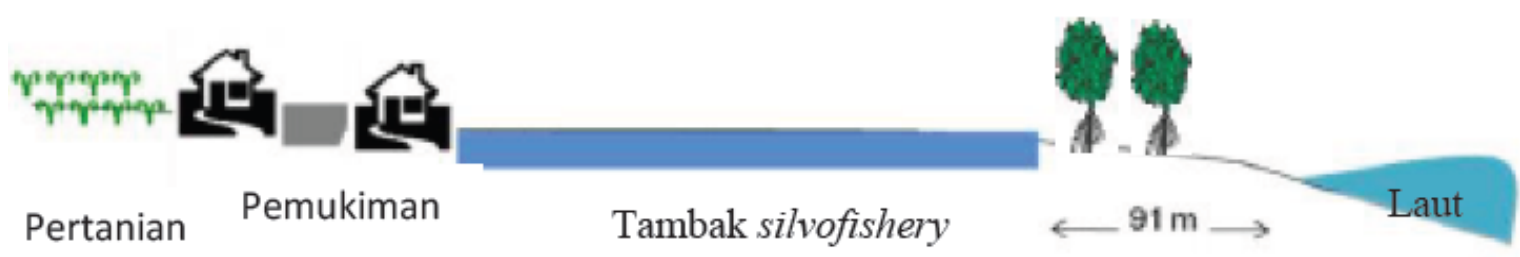

(Jalur Hijau ) 
WIIP (kom. pri, 2011) telah memformulasikan solusi yang dapat menunjang aspek ekologi, dan sosial ekonomi maka pembuatan jalur hijau sebaiknya dalam bentuk tambak tumpangsari di wilayah pertambakan masyarakat dengan luas \pm 520 ha. Tambak tumpangsari memiliki kelebihan dalam bidang ekologi, ekonomi, dan pariwisata. Apabila tambak tumpangsari dapat dimanfaatkan dengan baik, maka semua pihak akan lebih diuntungkan dalam berbagai aspek. Dalam pelaksanaan sistem ini dapat diperoleh keuntungan, yaitu: (i) Meningkatkan pendapatan masyarakat sekitar mangrove dengan hasil pemeliharaan hutan. (ii) Menjamin kelestarian hutan mangrove. (iii) Daerah penyangga untuk kawasan Cagar Alam Pulau Dua. (iv) Menjadikan daya tarik tersendiri di bidang pariwisata alam. Melihat kondisi tambak di Desa Sawah Luhur yang terletak berbatasan dengan jalan raya sampai dengan bibir pantai maka tambak tumpangsari yang difungsikan sebagai jalur hijau terletak di tambak masyarakat yang berbatasan dengan jalan raya sampai pada bibir pantai.

\section{KESIMPULAN}

Berdasakan hasil kajian terhadap kebijakan yang terkait penetapan lebar jalur hijau dapat disimpulkan bahwa Perda Kota Serang No. 6 Tahun 2011 tidak mengatur penetapan lebar jalur hijau secara rinci. Untuk panjang garis pantai 4,97 km dan lebar jalur hijau $91 \mathrm{~m}$ menurut Keppres No. 32 Tahun 1990 maka luas jalur hijau yang seharusnya ada 45,18 ha, sedangkan dalam kenyataannya wilayah yang ditumbuhi mangrove hanya 50,19\%. Terjadi kerusakan ekosistem di wilayah pesisir Sawah Luhur akibat adanya abrasi dan banjir rob serta Intrusi yang sudah mencapai 4 km mengakibatkan kekurangan air bersih untuk kehidupan masyarakat. Solusi yang dapat digunakan adalah pembuatan jalur hijau dalam bentuk tambak tumpangsari pada lahan pertambakan dengan luasan \pm 515 ha. Model tambak tumpangsari merupakan solusi yang bijaksana dalam memenuhi kepentingan masyarakat akan tingginya pemanfaatan lahan (sosial ekonomi) dengan mempertimbangkan aspek ekologi.

\section{REFERENCES}

Badan Perencanaan Pembangunan [Bappeda] Kota Serang. 2008. Rencana Pembangunan Jangka Menengah Daerah (RPJMD) Kota Serang Tahun 2008-2013. Badan Perencanaan Pembangunan Kota Serang. Serang.

Dewi RH. 1995. Pengaruh Kerapatan Tegakan Mangrove Terhadap Aspek Ekologis Tambak Tumpangsari (Silvofishery) (Studi Kasus di KPH Cibuaya, Besar Pengembangan Budidaya Air Payau) [tesis] Program Pascasarjana Institut Pertanian Bogor.

Direktorat Tata Guna Tanah. 1973. Pola Penggunaan Tanah Sebagai Indikator Tingkat Pencemaran Lingkungan Hidup. Publikasi No. 33. Direktorat Jenderal Agraria, Departemen Dalam Negeri. Jakarta.

DKP [Departemen Kelautan dan Perikanan]. 2007. Pedoman Pengelolaan Ekosistem Mangrove. Jakarta: Direktorat Jenderal Kelautan, Pesisir dan Pulau-Pulau Kecil, Direktorat Bina Pesisir.

Gusrina. 2008. Budidaya Ikan Jilid 1. Jakarta: Pusat Perbukuan Departemen Pendidikan.

Hanson AJ, Koesbiono. 1977. Peranan Periklanan dalam Perencanaan dan Perencanaan dan Pengembangan Daerah Pantai. Seminar Pengelolaan Sumberdaya Air, Ekologi Pembangunan. Lembaga Ekologi Unpad, Bandung.

Keppres No. 32 Tahun 1990 mengenai Pengelolaan Kawasan Lindung Koeswadji H, Mukono J, Soegiyanto, Laksminiwati E. 1986. Batas Lebar Jalur Hijau Hutan Mangrove : sebuah catatan tentang payau bakau dan pengelolaannya. Prosiding III Diskusi Panel Daya Guna dan BatasLebar Jalur Hijau Mangrove. Panitia Nasional Program MAB Indonesia LIPI, Jakarta.

Kusmana C, Wilarso S, Hilwan I, Pamoengkas P, Wibowo C, Tiryana T, Triswanto A, Yunasfi, Hamzah. 2003. Teknik Rehabilitasi Mangrove. Bogor: Fakultas Kehutanan Institut Pertanian Bogor.

Pariwono JI. 1989. Gaya Penggerak Pasang Surut. P3O-LIPI. Jakarta. Hal. 13-23

Pemdes Sawah Luhur. 2008. Monografi Desa Sawah Luhur 2008. Pemdes Sawah Luhur, Serang

Perda Kota Serang No. 6 Tahun 2011 mengenai Rencana Tata Ruang Wilayah Kota Serang tahun 2010-2030.

Pusat Riset Teknologi Kelautan. 2002. Penanganan Abrasi, Erosi, dan Tsunami dengan Optimasi Vegetasi. Pusat Riset Teknologi Kelautan, Jakarta

Soemarno. 1986. Peranan Jalur Hijau Mangrove Terhadap Pelestarian Sumberdaya Perikanan. Diskusi Panel Jalur Hijau, Ciloto.

Sualia I. 2010. Kajian Singkat Aspek Hidro-Oseanografi Lokasi Wetlands Livelihood Project Pemalang dan Teluk Banten. Laporan Penelitian Wetlands International Indonesian Programme. Bogor.

Wyrtki K. 1961. Phyical Oceanography of the South East Asian Waters. Naga Report Vol. 2, Institute Oceanography, California. 